\title{
Determinants of Singlehood: a retrospective account by older single women in Lagos, Nigeria
}

\author{
Ntoimo Lorretta Favour Chizomam ${ }^{1}$ \\ Email: ntoimof@yahoo.com, lorretta.ntoimo@fuoye.edu.ng \\ Tel.: 234-8037672580, 234-8023433641 \\ Uche Isiugo-Abanihe ${ }^{2}$ \\ Department of Sociology, University of Ibadan, Nigeria \\ Email:ucheabanihe@yahoo.com, Tel.: 234-8037135054
}

Department of Demography and Social Statistics, Federal University Oye-Ekiti, Ekiti State, Nigeria.

\begin{abstract}
Although the population of older never married women in Nigeria is increasing considerably, negligible attention has been paid to this emerging social reality. This paper examined the determinants of singlehood from the life experience of never married women. Aspects of Giddens' Structuration theory provided theoretical framework for the study. Empirical Data were drawn from twenty-seven In-depth Interviews, two Life Histories, and seven Focus Group Discussions conducted between 2010 and $201 \mathrm{I}$ in Lagos, Nigeria with involuntary and childless never married women aged 30 and above. The major determinants of singlehood among them were drive for economic empowerment and financial independence, personal mate selection preference, marital experience of other women, cultural beliefs and practices, family background factors, and higher education. Increasing singlehood among women threatens Nigeria's traditional nuptiality pattern of early and universal marriage and could become one of the most important components of demographic transition in $2 I^{\text {st }}$ century Lagos.
\end{abstract}

Keywords: Singlehood, women, marriage, economic empowerment, lagos

\section{Résumé}

Bien que le taux des femmes non mariées au Nigeria s'augmente, une attention négligeable $a$ été accordée à cette situation sociale émergente. Cette étude détermine le nombre des femmes célibataires âgées de 30 ans et plus, jamais mariées et sans enfants. Le cadre de cette étude est basé sur des aspects de la théorie de structuration fournis par Giddens. Les données empiriques ont été tirées de 27 enquêtes profondes, deux histoires de vie, et de sept groupe de discussions des femmes non mariées et sans enfants âgées de 30 ans et plus, menée entre 2010 et 201 I à Lagos, au Nigeria. Parmi eux, les principaux déterminants du statut célibataires ont été établis sur certains facteurs y compris l'autonomisation financière et économique, des préférences personnelles dans la sélection des copains, l'expérience maritale de certaines femmes, des croyances religieuses et pratiques culturelles, des conditions familiales ainsi que l'enseignement supérieur. Le taux croissant des femmes célibataires menacent le modèle traditionnel nuptial au Nigeria ; le mariage précoce et universel pourrait devenir l'une des composantes les plus importantes de la transition démographique à Lagos au 2 l eme siècle.

Mots clés :Célibataire, femmes, mariage, autonomisation financière, Lagos.

\section{Introduction}

Marriage is the important marker of adult status in Nigeria (Smith, 2007; Agbasiere, 2000; Uchendu, 1965). Prolonged non marriage is essentially disapproved in any Nigerian setting, and permanent non marriage for women has no place in Nigeria's sociocultural system, except for women who are religious celibates or espoused to "spirits" as priestesses (Ezumah, 2008; Otite, 2006; Agbasiere, 2000; Isiugo-Abanihe, 1994). Every woman is expected to marry and remain married all her life; and women derive their status basically from their dyadic roles of wife and mother. A study among the Igbo of Southeast Nigeria, for instance, observed that "a girl's life is essentially a preparation for marriage ... a woman's glory is her children, and to have children, she must have a husband" (Uchendu, 1965:53). Nevertheless, changes that are transforming this characteristic nuptial behaviour have continued to take place at both the macro and micro levels. The percentage never married among women age 30 and above has consistently increased in Nigeria, from 3.4 percent in 1991 to 6,7 percent in 2006. In Lagos,

I. Correspondence author. 
over 7 percent of women aged 30 to 85 are never married (NPC, 1998, 2009)

Although singlehood is increasingly becoming a social reality in Nigeria, the fact of its determinants is not known through empirical research. Nigeria's population census and Demographic and Health Surveys provide indications on increasing male age at first marriage, likely marriage squeeze and other demographic factors as likely causes of increasing singlehood among older women. But such data cannot provide detailed information on the experience of individual single women with respect to the causes of singleness as well as their perspectives on singleness.

Taking all these into consideration, this study explores the question of why women who wish to marry remain single into their thirties and above. Following Bryne (2000), singlehood is defined in the study to comprise women age 30 years and over, never married, childless, not cohabiting. This definition excludes religious celibates and women who are never married as a result of disability. Most women marry for the first time in their 20s, therefore, many demographers and family scholars use the age marker of 30 or 35 years to distinguish younger never married women from older ones (Ibrahim and Hassan, 2009; Macvarish, 2006; Byrne 2003; Simpson, 2003; Ferguson, 2000). In societies such as Nigeria where marriage is strongly associated with motherhood, marriage after age 30 , which is the upper limit of the most fecund years, for women, is considered late.

\section{Literature review and theoretical framework}

It is evident from the literature that the number of older single women is increasing in many countries, especially among urban based highly educated and economically independent women (Ibrahim and Hassan, 2009; Tanturri and Mencarini, 2008; Koropeckyj-Cox and Call, 2007; Berg-Cross, et al., 2004; Isiugo-Abanihe, 2000).

A number of demographic and non demographic factors have been identified by demographers, family scholars and other researchers as determinants of singlehood phenomenon. Socio-economic transformations and individualism embedded in modernism are linked to increasing postponement or outright rejection of marriage by women and men in many countries (Giddens, 2006). According to Smith (1980), in nearly every non-western society the process of social change has resulted in later marriage for both men and women. Corroborating this, Isiugo-Abanihe (2000) observed that the tendency to postpone and reject marriage is structurally linked to economic development and social transformation. Berg-Cross et al (2004) argued that the globalisation of economic empowerment of women is one strong reason why women postpone or reject marriage the world over. Economic opportunities and independence reduce women's desire to marry for economic reasons, especially if they have sure and stable means of livelihood (Isiugo-Abanihe, 2000, 1998; Ferguson, 2000; Carr, 2002; Tanturri \& Mencarini, 2008). Having less desire to enter into a union increases the likelihood of remaining single (Goldscheider and Waite, 1986 cited in Dykstra and Poortman, 20I0).

Economic empowerment fuelled by individualism and education are known to raise women's expectations and requirements for a desired partner (De-Silva, 2000; Berg-Cross et al., 2004; Giddens, 2006; Koropeckyj-Cox \& Call, 2007; Tanturri \& Mencarini, 2008; Alam et al., 2008; El-Halawany, 2009; Dykstra \& Poortman, 2010). High expectation about marriage and would-be partner reduces one's chances of marriage. Idealised image of marriage and suitable marriage partner and unwillingness to accept compromise as a strategy for forming relationship is a reason for singlehood (Kalmijn, 1998). Berend (2000) noted that in the nineteenth century New England, older never married women are those who are less willing to compromise their values on marriage and family life. The single women as well as married women take the ideals of marriage and love seriously, and they consider a happy marriage the happiest condition of human life, and would rather have the best or none. Idealising marriage and unwillingness to accept compromise are found to be reasons for increasing number of single never married mothers (Siegel, 1995), and older never married women in countries such as Egypt, USA, Poland, Germany, India, where educated and highly educated women do not want to lower their desiderata for an ideal marriage mate, just to marry (El-Halawany, 2009; Berg-Cross et al., 2004).

Furthermore, what a man seeks in a prospective wife is influenced by prevailing macro level factors such as gender norms and ideologies. In societiessuch as Nigeria, where women are socialised and expected to be dependent and docile (Omokhodion, 2009; Oderinde, 2002); and wealth or financial independence are associated with masculinity (Smith, 2007), possession of much economic resources position women at a disadvantage in their local marriage markets. A research finding shows that whereas possessing many economic resources increases men's likelihood of union formation; it decreases likelihood for women (Dykstra and Poortman, 2010).

Increasing self-selection of marriage partner and insistence on love are elements of modernism that 
are also found to promote singlehood (Berg-Cross et al., 2004; Giddens, 2006. The rising prevalence of single professional women is attributed to the globalisation of love as a primary factor in mate selection (Berg-Cross et al. 2004). Studies in Nigeria have observed consistent decline in arranged marriage, parental and kinship control in spouse selection (Smith, 2007; Ekiran, 2003; Isiugo-Abanihe, 1995). Some researchers have predicted that as gender roles become alike, women gain occupational and economic equality with men, and kinship control wanes, exchange in the marriage market will be based more on expressive, affective, sexual and companionship, resources, and earning potential (Buss et al., 200I; Isiugo-Abanihe, 2000). Corroborating this notion Berg-Cross et al. (2004) argued that erotic love has become a globalised primary stimulus for mate selection. Dykstra and Hagesatd (2007) argued that as more women enter into the labour force on equal footing with men, "fathering", the practice of care and relationship building with one's children, becomes more important for women in choice of suitable marriage partners, than men's economic ability. Hakim (2010) argues in her erotic capital theory, that physical and sexual attractiveness is a strong basis for mating and marriage in the modern self-selection marriage market. Women who are physically attractive attract men of higher status and marry younger. Hakim further argues that in the modern marriage market, men are also assessed by their physical attractiveness, although the standards are higher for women. Men who are not physically attractive "must offer substantial compensating benefits in wealth, effort, and willingness to please" in order to attract a suitable mate.

Another related factor that has been found to have influenced never married women's marital decisions in ways that lead to singlehood is family background. Prominent among the family background factors is marriage of significant others such as parents, guardians and other close relatives, birth order, domestic violence, divorce and separation. Conflictual and unhappy parents' marriage is found to have negative effect on daughter's desire and opportunity to marry in ways that prolong marital delay and lead to permanent voluntary or involuntary singlehood (Ferguson, 2000; Siegel, 1995; WaKaranja, 1987). Growing up in a mother-only family is linked to remaining single. A research found that females reared in a one parent family, whether it is the father or mother, tend to remain single probably due to greater family responsibilities and recognition of the advantages of singlehood (Forsyth and Johnson, 1996).

Other studies linked singlehood to causative factors, such as, demographic and non demographic marriage squeeze (Davidson \& Moore, 1996; De Silva, 2000; Berg-Cross et al., 2004), decline in polygny (Gage and Bledsoe 1994; Mann 1994), compulsory bride wealth and dowry (Isiugo-Abanihe, 1994, 2000; Mohammed, 2009; Mohammed, 2012), economic decline (De Silva, 2000).

Nevertheless, only few of these studies (Ibrahim and Hassan, 2009; El-Halawany, 2009) examined the causes of singlehood from the perspective of single women in developing societies where elements of modernity exist alongside traditional patriarchal structures and strong marriage and family ideology.

Aspects of modernisation theory, specifically Gidden's Structuration theory, were adopted to investigate singlehood in the context of particular features of modernity that affect individual choices and life experience. Giddens explains that modernity is characterized by distantiation, disembedding mechanism and reflexivity. Distantiation refers to time-space separation. Disembedding is the breakdown of geographical and time barriers in social interactions. Time-space distantiation and disembedding mechanisms, such as, money and expert systems in modern societies entail that the basis of trust is no longer personal knowledge (Ritzer, 2008). Reflexivity extends to all areas of social life including personal world views and decisions, and creation of self identity. In the modern society, people are no longer confined to roles and positions embedded in traditions. "Within the limits of the opportunities available to them people can increasingly shape who they are and who they think themselves to be" (Haralambos \& Holborn, 2008:5I3).

\section{Data and methods methodology}

This study employed qualitative techniques to collect data on factors that predispose women to singlehood. Twenty-seven in-depth interviews (IDI), seven focused group discussions (FGD) and two life histories $(\mathrm{LH})$ were conducted by the first author, with never married women who were involuntarily single and had no children, in metropolitan Lagos between 2010 and 2011 .

The interviews and group discussions were semi-structured and open-ended with series of probes and general questions to get the women to talk about their experiences in dating.. "The respondents were selected through the snowball technique. Care was taken to include single women of diverse backgrounds. The two life history cases were selected based on their relevant experiences with regard to possession of economic resources, mate selection, family background and remaining single. The seven focus groups comprised 41 participants. Participants in each group ranged from six to 
eight. Groups were constituted on the basis of specific focus of ethnic origin, level of education and profession. All interviews and discussions were conducted in English, tape-recorded, and transcribed verbatim. The transcripts were coded with Atlas-ti 6.2 by themes and sub-themes of interest to the study and content analysed. The study adhered to the four main areas of ethics in social science and qualitative research - informed consent, deception,

privacy and confidentiality, and accuracy. Although the researchers could not guarantee complete confidentiality and privacy for FGD participants, the discussants were strongly requested to respect each other's privacy by not discussing the issues outside the group.

\section{Results}

Table I Summary characteristics of the subjects

\begin{tabular}{ll}
\hline Characteristic & Distribution \\
\hline Total No of subjects & $\mathbf{7 4}$ \\
\hline Mean Age & 37.7 \\
Mean Annual Income $(\mathrm{n}=48)$ & $\mathrm{N} 689,000(\mathrm{US} \$ 4,593)$ \\
Ethnic Origin $(\mathrm{n}=69)$ & Igbo -27 \\
& Yoruba -23 \\
Religion & Others -19 \\
& Christianity -72 \\
\hline Highest Education Attained & Islam - 2 \\
& Tertiary - 47 \\
& Undergraduate - I \\
\hline Profession & Secondary - 26 \\
& Primary - Nil \\
\hline Birth Order (I daughter $)$ & Self-employed - 2I \\
\end{tabular}

\section{Determinants of Singlehood among Women in Lagos}

\section{Groundedness}

Objection by Parents/Near Relatives

The State

Circumstantial Factors

Aversion to Polygyny

Urbanisation

Differnces in Religious Affiliation

Personal Factors

Other Modern Lifestyle

Education

Family Background

Cultural Beliefs and Practices

Marital Experience of Other women

Mate Selection

Possession of Economic Resources

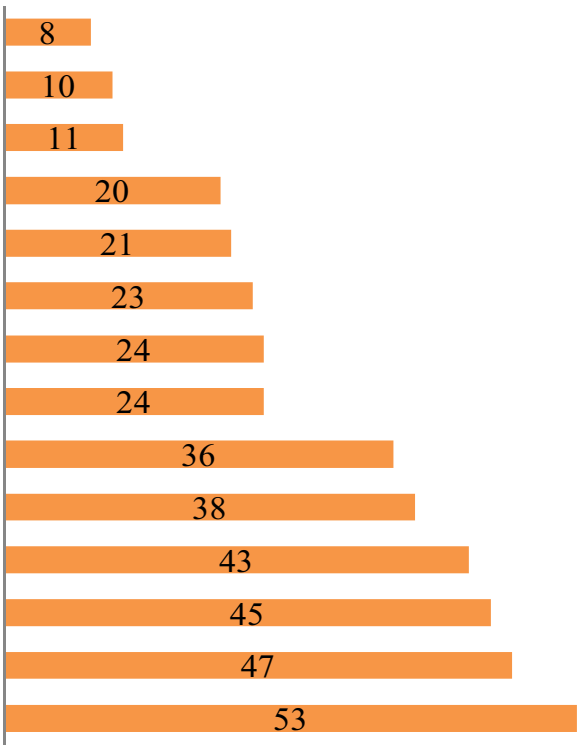

Fig. 1: Determinants of Singlehood among Women in Lagos 


\section{Single women's account of why they have never married}

The narratives of 74 single women gave a general overview of the determinants of singlehood among women in Lagos, as presented in Figure I above, in order of relative groundednes - the number of quotations associated with a particular theme. Responses in the in-depth interviews and focus group discussions showed similar results which were confirmed in the two life history interviews.

\section{Possession of economic resources}

Real or assumed high economic achievement limited the respondents' opportunity to marry due to persistent cultural stereotypical beliefs in Nigeria about women of high economic means. Such women are often seen as unmarriageable, arrogant and too independent. A 45-year old social development worker and university lecturer recounted her experience. Having a good job, a car and a rented flat made her appear too expensive for a man to maintain. A 43 year-old discussant observed that:

Sometimes men are intimidated or overwhelmed by women's status or even things as simple or trivial as women's poise or self confidence. (Res 3, FGD 6).

On the other hand, not having paid employment hindered marriage chances for women in Lagos as shown by the comments below:

Men are looking for women who are working, to help them (IDI 20, 3 I years old)

I think most men in Lagos want women who will contribute financially; they even prefer a fifty-fifty thing. It is more of a contract in Lagos. It is more like a partnership, you drop something, and then I drop too. They enjoy it. That's why most times women are like let me get what I need to get so that at least when the man comes ... (Res 3, FGD 7, 38 years old).

While seeking secure means of livelihood before marriage, marriage chances are forgone

Right from my first year in university, men were proposing marriage to me, but I didn't feel I should get married at that age because I felt I should work and be financially stable before marriage. I believe it is because if you are able to take care of yourself to an extent the pressure for you to just go into any kind of marriage or remain in a bad marriage is not there. Financial independence for the women encourages a woman who is in a very very bad marriage or bad situation to at least may be come out to take care of herself $(\mathrm{LH} \mathrm{I,} 44$ years old)

In addition, economic empowerment raised the desiderata for an ideal partner for some of the subjects, who were reluctant to marry men who were either unemployed or earned less. A 37 year-old qualified staff nurse emphatically said she would not dare enter into marriage with a man who has no sure means of livelihood.

I cannot see a man that is not working and he says he wants to marry me and I will agree, because I know I won't cope. He must be doing something to earn a living. He must be doing something that can feed him and me (Res 5, FGD 3).

Having attained economic independence, desire to enter into marriage for economic reasons declined for some of the women. An interviewee submitted that:

Mere looking at other people's marriage; in fact, let me be frank with I won't marry. I always ask God to bless me so that I will continue to be financially secure; I will be OK without a man (IDI I4, 40 years old).

\section{Mate selection preference}

The majority $(n=18)$ of the twenty-nine women involved in the in-depth and Life history interviews, who spoke directly about their particular reasons for remaining unmarried attributed their singlehood partly to their insistence on personal values about a suitable marriage partner.

Like the first proposal, he was already a graduate, an architect, who just left university. Then I felt he was short; and a couple of other proposals too, may be for different reasons too. At times I might say I don't like where you are from, I don't like you, you are not from my state. At that time maybe because of my age then, I said I wanted to marry from a particular place. There was one who was too light-skinned and I say aha you are too light I don't like light-skinned men. It's just like that for different reasons ... (LH I, 44 years old).

Many of the single women declined marriage proposals from men who did not meet their desired personal, economic, age, educational, ethnic/cultural, physical, and religion preferences. The dominant preferred personal resources of a would-be suitable spouse among the subjects were fear of God, love, care, honesty, and hard work. Inter-faith marriage was unpopular; only three subjects would marry men of another religion

Emphasising the rationale for self selection based 
on love and personal goals, a discussant expressed an opinion which was corroborated by other interviewees and discussants.

I think the reason why some women these days don't get married on time is because we realise that in the time past our parents lived unfulfilled life ... But now we understand that marriage can only make or destroy you as a woman. There are so many women out there whose lives are in shambles by reason of marriage. When you get close to them you find out that they are supposed to be great women in different areas of life but because of marriage every vision, every gift is shattered. So now, people are marrying based on you help me as a man I help you as a woman (Res. 2 FGD 2, 33 years old).

\section{Cultural beliefs and practices}

Cultural practices found to play prominent roles in determining singlehood in Lagos were physical/sexual attractiveness, normative marriage processes, cultural stereotypes about women, ethnic prejudice and endogamy, high bridewealth, pronatalism, and gender socialisation. Respondents who were not physically/sexually attractive even though they were domesticated lost marriage opportunities. Those who insisted on a formal marriage procedure, such as, traditional or church wedding also lost chances to marry. Cultural stereotypes, ethnic prejudice and endogamy hindered some of respondents from marrying when they were younger. High bride wealth, especially among the lgbo single women, was found to contribute to "scarcity" of Igbo men, who now marry from other ethnic groups where bride wealth is lower. In some cases, the expectation for a woman to conceive before marriage arrangement is concretised resulted into singlehood. Though the least of cultural practices that caused singlehood, it was found that women who are socialised to think they were like men tend to think they can always marry at any time just like men. IDI 2, for instance was a tomboy, she played football and hunted with boys, and never bothered about marriage until she was close to thirty. One of the respondents recounted:

Some of the men who come to me for marriage wanted to have sexual intercourse with me just to know whether I am could conceive ... I have a fiancé, we tried and I became pregnant, but I had miscarriage, and he insisted I had to wait (IDI I8, 39 years old).

\section{Family background factors}

Family background factors that featured prominently in the study were: marriage of significant oth- ers such as parents and siblings, family responsibilities and obligations, and birth order. Blissful marriage of parents encouraged women to desire men like their fathers, while conflictual parents' marriage encouraged them to avoid men with the traits of their fathers. Respondents whose parents had conflictual marriage whether in monogamous or polygynous union ( $n=7$ of 29 in-depth and life history interviews) had inclination to avoid men like their fathers.

I don't like the way my father treated my mother. It affected my choice of marriage partner. I made up my mind that I will not marry somebody like my father. So, anytime I see a semblance of my father in any man that comes around, that nullified it. Once I see a trait, I will say aha this is another Mr. ... (IDI 5, 47 years old).

There was a tendency for the women who thought their fathers were ideal men to idealise marriage so much that they were unable to find the real and presumed qualities of their fathers in other men. Respondents who emphasised such "father" qualities are likely to become victims of endless search for men who embody the masculine ideals found in their fathers, while those who detested their fathers' qualities or parents' conflictual marriage are also likely to become victims of endless search for "better" relationship.

Mother's experience in marriage specifically affected some of the respondents in the decisions about marriage. In the in-depth and life history interviews, many $(n=13)$ of the respondents said their mother's marital experience affected their impressions and decisions about marriage. Life history two was raised by a mother who was an "outside wife". Her mother's sad experience made her to become very restrictive in her mate selection.

I watched my Mom, sometimes you know, I think that was around my father's death, I asked her: "Why on earth did you choose to marry this man?" I asked her that because of what she went through ... I have seen mistakes that I want to correct in my own marriage if I eventually get married. ... But some times when I think about it, it was horrible. Whenever my Mom gave birth, sometimes you don't see my Dad until the eighth day, when they are supposed to name that child. ... So many experiences, sometimes you begin to ask yourself: is marriage worth it? Ok even if $\mathrm{I}$ am going into it let me be sure, you understand. ... One feels insecure because of past experiences and what you see around you ( 40 years old).

Family responsibility and obligations also limited 
opportunities for marriage for some of the respondents. Life History 2, for instance, had to raise five children of her late sister.

So, as I am sitting here no man wants to marry me with all those kids around me. I think that's what kept me up till this age, I know, I understand. No man, once they follow me home and see my responsibility, though some of them come back and we stay as friends but they will tell me they can't marry me. Nobody wants to marry a liability.

That's what has kept me.

Birth order as a first daughter obligated some of the single women to provide financial support for parents and siblings before marriage. Evidence for this factor as indicated by the groundedness showed that birth order was not a strong family-related reason for singlehood but it did hinder some of the women from marrying at their own time and term. Being the first child and daughter, IDI 5 narrated how she got involved in trading from her youth to augment the family income. She gave so much attention to her family welfare that she had no time for her personal welfare. She attributed her singlehood partly to her role as first daughter.

Being a first daughter affected me. I had to use my money to solve some family/domestic problem in the family. I had to struggle to pay school fees for my younger ones (47 years old).

\section{Education}

Several respondents $(n=35)$ referred to education as personal or perceived reason for marital delay in Lagos. The length of time it takes to acquire education inevitably postpones marriage for so many women because they would not marry while attending school. Life History subject three called off her first date because she wanted to complete tertiary education, she asserted that:

Maybe, that is what happened to most of these other single women, they wanted to be educated, but by the time you go through that, maybe you are already 30 or 28 , you serve [compulsory one year National Youth Service] before you get somebody to settle down with (LH 3, 46 years old).

Speaking on why some women insist on attaining a desired level of education before marriage a discussant observed:

If we say let us marry, our husbands will train us in school, it's a lie oh. By the time we give birth to one, two, three children, education is finished. ... By the time we enter, [marital union] honey and sweetie will end, and I will not go to school again (Res 3 in FGD 4, 30 years old).

Whereas women are getting educated and their values and preferences are improving, the cultural ideals of early marriage and traditional mate selection preference are evolving at a slower pace. Male mate selection still tilts in favour of women who are less educated than they are. This was implied in the statement below by a $3 \mathrm{I}$ year old interviewee.

When a woman is too educated, it limits the number of men who will come around her because men have ego. They want a woman they can control, a woman they are more than, not a woman that will seem to rule over them (IDI 20).

\section{Marital experience of other women}

One recurrent issue in the narratives of the subjects was experience of other women in marriage. What happens in the confines of a home seemed go a long way to chart the future of others who are not even near part of that home. Responses from the subjects in this study disclosed that women empathize with one another. The experiences and life of women affect other women's world view and expectations in life. From the experience of married women around them, respondents wanted to avoid the mistakes of women who have gone ahead of them into marriage. Marital experiences that are mentioned in this study as strong influences on the marital decisions of single women in Lagos include marital bliss, divorce and separation, intimate partner violence, structure and power relations in the home, and irresponsible fatherhood.

Unhappy and conflictual marital experience of other women sent discouraging signals to the never married women about marriage; and made their mate selection preference more restrictive. On the other hand, happy or blissful marriage experience of other women encouraged marriage and raised the expectation of women about marriage and would-be marriage partners. In her narration of reasons for non-marriage a respondent observed:

There are marriages you see and you will just be telling yourself if $I$ am not into this business, then I am missing a lot, because you have seen that there is love and harmony in the home. But, there are others you will see, you tell yourself if marriage is like this I rather stay on my own (IDI 17, 45 years old).

The most recent Nigeria's census (2006) shows that divorce rate in Nigeria is 13.4 per 1000 ever married persons age 10-85 years (NPC, 2009), but the respondents claimed that divorce rate is high in Lagos and other parts of Nigeria. Sad experiences of divorced or separated women known to the sub- 
jects encouraged them to wait longer for the "right man" or prepare ahead for divorce through economic empowerment.

Another reason why I think women are not getting married on time is divorce. It's very alarming. The rate at which marriages are crashing is very alarming and terrible. So, one has to be careful not to rush in and rush out (Res 5, FGD 2, 30 years old).

\section{Other modern lifestyle}

In addition to economic empowerment, education, and urbanisation which will be discussed later, other modern lifestyles such as intolerance for early marriage, violence, and partner infidelity, and influence of western culture were found to be determinants of singlehood among the study population. the following are excerpts from the narratives.

If I may use myself as example, my eldest sister got married early and she has ten children. My Mom married early and she had ten children though one is late. Early marriage makes a woman to give birth to so many children ... (Res 2, FGD 3, 36 years old).

I also believe that one of the causes of singlehood in Lagos is that we have a lot of foreign culture in our midst.. (Res 2, FGD 2, 33 years old).

In some marriages they fight. I don't want oh, if it is only this type of marriage, God don't allow me to marry and my husband slaps me (IDI 17, 35 years old).

\section{Personal factors}

Certain factors that were considered personal hindered some of the single women from entering into marital union before age thirty. These factors included unwillingness to become single mothers, unwillingness to date men/sexual abstinence, preference for date with married men, deliberate choice, and personal character. In response to a question on if she would consider single motherhood if there is no husband in view, a respondent replied:

I have met single women who say OK if I don't get married at this age I will just have a child and they have done that. From their experience I have found out that it wasn't a good decision. A child is not equal to a husband. I know two of such women; if you look at their lives now, one has a daughter and the daughter is putting pressure on her to take her to her father. So, it's always a problem and then of course I think the agreement she had with the man was that he did not want his identity revealed (LH I, 44 years old).

Expressing her preference for dates with married men, a respondent submitted:

I trust married men more than young men. I am telling you the truth. I love them more than young guys because they are there for you. They care for you, they give you advice, - the good ones. They tell you how you are going to live your life, even help you to build your future, I 'm telling you the truth. I have met that kind of a person. He helped me to build my future, he advised me. I am telling you the truth ... All these young men are not faithful at all (IDI I4, 40 years old).

This respondent was conflating her married sexual partners' generousity with faithfulness, whereas extra-marital affair is unfaithfulness to their legal wives. Preference for married men as one of the causes of singlehood in Lagos was corroborated in the focus group discussions.

\section{Differences in religious affiliation}

Insistence on religious identification and values was found to be one of the reasons for prolonged delay in marriage for women in this study. The respondents were very unwilling to enter into inter faith marriage; only three of them would marry a man who is of a different religion. IDI 4, for instance, attended a protestant church, she met men who were Roman Catholics; in each case, she declined their marriage proposals. Others, in the in-depth interviews and group discussions, had similar experiences. A respondent who declined marriage proposals from men who are of another Christian denominations, recalled that her father strongly objected to her stand.

My father kept saying a woman doesn't have

a church; you go to where your husband is

(IDI 4, 42 years old).

Nonetheless, this respondent believed her father's idea is just tradition which she was not liable to follow.

\section{Urbanisation}

One of the strong reasons for singlehood in Lagos identified by the study subjects was the influence of urbanisation and city life. In the interviews and group discussions, urban factors such as urban men's preference for casual sexual relationships and consensual union, negative stereotypes about city women and urban environment were shown to have influence on women's opportunity to marry. A 32-year old Health Insurance Executive insisted that

City men are not serious. Let me just put it 
that way, they are not serious. They just want a relationship that will not end in marriage.

They want to play around (IDI 21 ).

Narrating her experience with regard to negative stereotypes about city women, a participant in a group discussion avowed:

I don't know how they see Lagos girls. It's like that, most men will befriend girls in Lagos but when they want to get married they will move down to the village to marry ... They say Lagos girls are too exposed (Res I, FGD 5,33 years old).

Urban environment was one of the reasons why some women remained unmarried till age 30 and above. Some of the respondents said Lagos is like a "no man's land"; social control mechanisms are limited. Women, as well as men have "too much" freedom.

\section{Aversion to polygyny}

Evidence from this study showed that the contemporary woman in Lagos may prefer permanent singlehood to polygynous union. A respondent in a focus group discussion, whose statement was like a synopsis of other participants' opinion about polygyny said:

Getting involved in a polygynous marriage defeats the purpose of marriage, therefore, it is better to remain single (Res 2, FGD 6, 40 years old).

Asked whether she would marry as a second wife, the Yoruba Muslim respondent replied:

I have something against polygyny. I can't share my husband; and I don't want anybody to share with me (IDI 2I, 32 years old).

\section{Circumstantial factors}

There were determining factors of singlehood which are considered circumstantial because they were caused by factors external to the single women. Such factors included disappointment or broken courtship, death of intended spouse, and zero marriage proposals. Narrating her experience with regard to broken engagement, a respondent said:

Then, disappointment can occur, that is my own case, like broken relationship. You start with somebody then you call it off. You meet another person, something like that occurs and looking at it it's not your fault (LH 3, 46 years old).

Some respondents said because men keep multiple pre-marital sexual relationships with women; eventually they have to marry one, and the others will be disappointed.

\section{State-related factors}

Some respondents linked increasing singlehood in Lagos to economic downturn in Nigeria. Due to economic decline, it takes men longer time to be ready for marriage. As it is taking men longer time to establish financial resources expected for marriage, women who are in relationship with such men face the danger of being dropped eventually. In response to the reasons for singlehood in Lagos, a discussant observed:

The economy, the situation of the country is a cause of singlehood. Some matured women were in a relationship for so long expecting that things will get better and they will wed. Probably, by the time things got better for the man, he discovered that the woman was not good enough for his new status (Res 2, FGD 7, 37 years old).

\section{Objection by parents and near relatives}

Objection by parents and near relatives had minimal influence on marital decisions and opportunities for women in this study. A few respondents lost marriage opportunities because their parents objected. Recounting her experience, a discussant said:

I even wanted to marry a white man but my parents refused. If I knew I would have married him and be gone (Res I, FGD 5).

\section{Discussion}

The life experience of 74 single women in metropolitan Lagos highlighted diverse non-demographic factors that give rise to singlehood in Lagos. The major determinants of the current rate of singlehood in Lagos were economic empowerment, mate selection preference, marital experience of other women, and cultural practices and beliefs. Other factors were family background characteristics, such as, blissful or conflictual marriage of significant others, obligations to family of orientation, birth order; education, modern lifestyle, differences in religious affiliation, urbanisation and aversion to polygyny.

Previous studies found similar outcomes in different societies. Economic empowerment and education of women driven by modernity is strongly associated with later age at first marriage in many countries (De-Silva, 2000; Berg-Cross et al., 2004; Giddens, 2006; Koropeckyj-Cox \& Call, 2007; Tanturri \& Mencarini, 2008; Alam et al., 2008; El-Halawany, 2009; Dykstra \& Poortman, 2010). Individual preferences are a strong determining factor of finding or being found in the marriage market. Those whose preferences match their local marriage market, marry, while those whose preferences do not 
match the available market resources will either compromise their expected resources or remain single (Kalmijn, 1998; Raley \& Bratter, 2004). The experiences of the research subjects with regard to mate selection preferences confirm the effect of modernism, feminism and individualism in the personal life choices of women. Tradition still has a place in their world view; however its influence is fast being eroded. The emphasis is no longer on communal and kingship goals, individual values, gains and goals are fast becoming the primary impetus in spouse selection. Giddens posits in his Structuration theory that modernity is characterised by expression of more reflexivity in all aspects of life including choice of who to marry. Choice in modernity, according to him, will be based on individual preferences and gains rather than on traditional expectations (Giddens, 2006).

Cultural beliefs and practices hindered the women's chances of marriage. Cultural practices, such as, sexual or physical attractiveness, connects people to more desirable rewards ((Langlois et al., 2000 cited in McNulty, Neff \& Karney, 2008; Hakim, 2010). Marriage of significant others and other women known to the respondents limited marriage opportunities for them. Marital experiences of other women, such as, divorce and unhappy marriage have been found to influence marital decisions of never married women (Lamanna \& Riedmann, 2003; Sharp \& Ganong, 20II). Past studies link blissful or conflictual parents marriage (Ferguson, 2000), and single parents' household (Forsyth \& Johnson, 1996) to decisions that lead to singlehood. The findings on the influence of urbanisation and city life confirms studies that associate increasing number of older never married women to urban life (Isiugo-Abanihe, 2000; Berg-Cross et al., 2004) and men's preference for consensual relationship to difficulty in sole breadwinning (Dowd and Pallotta, (2000 cited in Lamanna \& Riedmann, 2003; Iwasawa, 2004; Dykstra and Poortman 2010). Aversion to polygyny which is also an urban lifestyle is associated with increasing singlehood (Gage \& Bledsoe, 1994).

This study provides empirical evidence to authenticate the notion that the universality of marriage in Nigeria is being threatened. Writing on the rising female age at marriage in Nigeria, IsiugoAbanihe (2000) attributed the change to breakdown of traditional pattern of mate selection and norms of early and universal marriage, increasing female education, migration and social emancipation. The reasons for singlehood found in this research confirm his observation, indicating that traditional pattern of early and universal marriage in Nigeria will continue to disintegrate, as the factors that give rise to singlehood continue to expand.

\section{Conclusion}

Life experience of seventy-four never married women aged 30 to 48 showed that singlehood among women in Lagos is occasioned by economic, cultural, institutional, personal, religious, and circumstantial factors.

The primacy of economic resources as a determinant of singlehood among women calls for further research on the effects of emerging economic opportunities in Nigeria on women, family formation and living arrangements. The effect of other women's marriage experience on the marital decisions and opportunity of never married women underscores the importance of enhancing gender equality. All forms of social and cultural norms that undermine and restrict women in the home should be eliminated, because what happens to one woman affects other women. Domestic violence should to be treated more as a public issue and a form of social violence than a private affair. The violence against women (Prevention, Protection and Prohibition Act 2002) should be domesticated in all States and effectively implemented.

Singlehood is a shift away from the traditional culture of early and universal marriage. Therefore, understanding the causes of singlehood in Lagos provided a necessary indication of what is happening to marriage, not only in Lagos but in Nigeria as a whole, considering that Lagos is the largest concentration of the multiple ethnic groups of Nigeria. This study therefore, adds to the much needed substantive knowledge of nuptiality patterns which is relevant for more effective population policies. Marriage patterns play significant roles in determining fertility and population growth rates. The study recommends replication of this study in other parts of Nigeria and Africa, and among men.

\section{References}

Agbasiere, J. 2000. Women in lgbo life and thought. London: Routledge.

Alam, R., Mondol, D. K., Tapan, K. R., Rahman, S. 2008. Effect of the working status of Bangladeshi women on age at marriage and fertility. Pakistan Journal of Social Sciences, 5(5):493-497.

Berend, Z. 2000. The Best or none! Singlehood in nineteenth-century New England. Journal of Social History, 33(4):935-957.

Berg-Cross, L., Scholz, A., Long, J, Grzeszcyk, E., and Roy, A. 2004. Single professional women: a global phenomenon challenges and opportunities. Journal of International Women's Studies, 5(5):3459.

Buss, D. M., Shackelford, T. K., Kirkpatrick, L. A., Larsen, R. J. 200 I. A half century of mate 
prefereces: the cultural evolution of values. Journal of Marriage and Family, 63(2):49I-503.

Byrne, A. 2000. Singular Identities: Managing Stigma, Resting Voices. Women's Studies Review, 7:1324

Byrne, A. 2003. 'Developing a sociological model for researching women's self and social identities'. European Journal of Women's Studies (Special Issue on Identities), I0(4): 443-464.

Carr, D. (2002). The psychological consequences of work-family tradeoffs for three cohorts of women and men. Social Psychology Quarterly, 65, 103-1 24.

Davidson, J. K. and Moore, N. B. 1996. Marriage and family: change and continuity. Boston, USA: Allyn and Bacon.

De Silva, W. I. 2000. Correlates of marital postponement in Sri Lanka. The Journal of Family Welfare, 46(2): 42-50.

Dykstra, P. A. and Hagestad, G. O. 2007.

Childlessness and parenthood in two centuries: different roads different maps? Journal of Family Issues, 28(II):I5I8-I532.

Dykstra, P. A. and Poortman, A. 2010. Economic resources and remaining single: trends over time. European Sociological Review, 26(3):277-29

Ekiran, M. A. 2003. Marriage and the family: a sociological perspective. Lagos: Rebonik Publications Limited.

El-Halawany, R. 2009. Spinsters' by choice: Egypt's single ladies speak out. Daily News Egypt, October 22. Retrieved Jan. 8, 2010 from http:// www. Thedaily newsegypt.com/article

Ezumah, N. N. 2008. Perception of womanhood in nigeria and the challenges of

development. Retrieved May, 2020 I I from http:// www.uct.ac.za.

Ferguson, S. J. 2000. Challenging traditional marriage: never married Chinese American and Japanese American women. Gender and Society, I4(I): 136-159.

Forsyth, C.J. and Johnson, E.L. 1996. A sociological view of the never married. books.google.com.

Gage, A. J. and Bledsoe, C. 1994. The effects of education and social stratification on marriage and the transition to parenthood in Freetown, Sierra Leone. Nuptiality in sub-Saharan Africa: contemporary anthropological and demographic perspective. C. Bledsoe and G. Pison. Eds. Oxford: Carendon Press. 148-164.

Giddens, A. 2006. Sociology. $5^{\text {th }}$ ed. Cambridge: Polity Press.

Hakim, C. 20I0. Erotic capital. European sociological Review, 26(5):499-518.

Haralambos, M. and Holborn, M. 2008. Sociology themes and perspectives. $7^{\text {th }}$ ed.
London: HarperCollins Publishers Limited.

Ibrahim, R. and Hassan, Z. 2009. Understanding singlehood from the experiences of nevermarried Malay Muslim women in Malaysia: some preliminary findings. European Journal of Social Sciences, 8(3): 395-405.

Isiugo-Abanihe, U. C. 1994. Consequences of bridewealth changes on nuptiality patterns among the lbo of Nigeria. Nuptiality in subSaharan Africa: contemporary anthropological and demographic perspective. C. Bledsoe and G. Pison. Eds. Oxford: Carendon Press. 74-91. . 1995. Bridewealth, marriage and fertility in the East-Central States of Nigeria. Genus, LI(3-4): I5I-I78. . 1998. Stability of marital unions and fertility in Nigeria. Journal of Biosocial Science, 30(I): 33-4I.

2000. Female age at marriage and proportions marrying in Nigeria.African Population Studies, 15(2): 43-65.

Iwasawa, M. 2004. Partnership transition in contemporary Japan: prevalence of childless noncohabiting couples. The Japanese Journal of Population, 2(I):76-92

Kalmijn, M. 1998. Intermarriage and homogamy: causes, patterns, trends. Annual Review Sociology, 24:395-42I.

Koropeckyj-cox, T. and Call, V. R. A. 2007. Characteristics of older childless persons and parents - cross-national comparisons. Journal of Family Issues, 28(10): I 362-I4I4..

Lamanna, M. A. and Riedmann, A. 2003. Marriages and families - making choices in a diverse society. $8^{\text {th }}$ ed. Belmont, USA: Wadsworth/Thomson Learning Inc.

Macvarish, J. 2006. What is 'the problem' of singleness? Sociological Research Online, II (3).

Mann, K., 1994. The Historical roots and cultural logic of outside marriage in colonial

Lagos. Nuptiality in sub-Saharan Africa: contemporary anthropological and demographic perspective. C. Bledsoe and G. Pison. Eds. Oxford: Carendon Press. 167-193.

McNulty, J. K, Neff, L.A. and Karney, B. R. 2008. Beyond initial attraction: physical attractiveness in newlywed Marriage. Journal of Family Psychology, 22(I):135-143.

Mohammed, E. 20I2. UAE concerns over sharp rise in spinsters. AFP. July I. Retrieved July 2, 29/2 from http://www.google.com/hostednews/afp/ article.

Mohammed, G. 2009. Increasing number of unmarried women in Jordan raises alarms.

December 31. Retrieved Oct. 3, 2010 from http:// al-shorfa.com/en_GB/articles/meii/ 
featurs/main/2009/12/3 I/feature-02

National Population Commission (NPC). 1998. 1991 Population census of the Federal Republic of Nigeria. Abuja: NPC.

National Population Commission (NPC). 2009. 2006 Population census of the federal republic of Nigeria. Abuja: NPC.

Oderinde, O. 2002. Equal rights policies and the multiple roles of women. Women and the culture of violence in traditional Africa. D. Akintunde and H. Labeodan. Eds. Ibadan: Sefer Books Ltd. 2840.

Omokhodion, J. O. 2009. Linking the dominance of house girls in Nigerian households to the girlchild socialization pattern in Nigeria. Current Research Journal of Social Sciences, I (2): I-3.

Otite, R. E. 2006. The Urhobo woman. Ibadan: Gold Press Limited.

Raley, K. R. and Bratter, J. 2004. Not even if you were the last person on earth! how marital search constraints affect the likelihood of marriage. Journal of Family Issues, 25(2): I67-I8I.

Ritzer, G. 2008. Sociological theory. $8^{\text {th }}$ ed. New York: The McGraw-Hill Companies, Inc.

Sharp, E. A. and Ganong, L. 20I I I'm a loser, i'm not married, let's just all look at me: ever-single women's perceptions of their social environment. Journal of Family Issues, 32(7):956-980.

Siegel, J. M. 1995. Looking for Mr. right? older single women who become mothers. Journal of Family Issues, I 6(2): |94-2II.

Simpson, R. 2003. Contemporary spinsters in the new millennium: changing notions of family and kinship. Gender Institute Working papers, London School of Economics. Retrieved Sept. 23, 2009 from http://eprints.Ise.ac.uk/37936/.

Smith, P. C. 1980. Asian marriage patterns in transition. Journal of Family History, Spring 52-96.

Smith, D. J. 2007. Modern marriage, men's extramarital sex, and HIV risk in Southeastern Nigeria. American Journal of Public Health, 97(6):997-1005.

Tanturri, M.L. and Mencarini, L. 2008. Childlessness in Italy. Population and Development Review, 34(I):5 I-77.

Uchendu, V. C. 1965. The Igbo of Southeast Nigeria. New York: Holt, Rinehart and Winston.

Wa Karanja, W., 1987. 'Outside wives' and 'inside wives' in Nigeria: a study of changing perceptions in marriage. Transformations of African marriage. D. Parkin and D. Nyamwaya. Eds. Manchester: Manchester University Press. 247- 26I. 